\title{
Consumers' Intention towards Halal Food in Low-Cost Airlines in Kelantan, Malaysia
}

\author{
Zul Ariff Abdul Latiff \\ Faculty of Agro Based Industry, Universiti Malaysia Kelantan, Jeli Campus, 17600 Jeli, Kelantan, Malaysia \\ Email: zulariff@umk.edu.my \\ Maizatul Vanisha Masril \\ Faculty of Agro Based Industry, Universiti Malaysia Kelantan, Jeli Campus, 17600 Jeli, Kelantan, Malaysia \\ Rivitra Vintisen \\ Faculty of Agro Based Industry, Universiti Malaysia Kelantan, Jeli Campus, 17600 Jeli, Kelantan, Malaysia \\ Mardini Zahidi Baki \\ Faculty of Agro Based Industry, Universiti Malaysia Kelantan, Jeli Campus, 17600 Jeli, Kelantan, Malaysia \\ Nursalwani Muhamad \\ Faculty of Agro Based Industry, Universiti Malaysia Kelantan, Jeli Campus, 17600 Jeli, Kelantan, Malaysia
}

\begin{abstract}
Low cost airline is the airline that excluding many traditional passenger services and offers generally low fares in exchange. In-flight meal is one of the services that being offered in the low-cost airlines, but the passenger must pay for it. The acceptation of halal food in Malaysia is still low compared to neighbouring country. This study is aimed to identify the intention's level of consumers and the relationship between religion and consumers intention towards Halal food in low-cost airlines. A self-administered survey was conducted using a structured questionnaire to collect data from the survey respondents. 75 respondents were involved in this study. Purposive sampling technique has been used, and the questionnaire form was designed and adapted based on the 'TPB' model. The data collected are entered and analysed using computerizes programmed of SPSS version 21.0. The analysis used is descriptive analysis and Chi-Square analysis. The result illustrates that consumers are mostly at the moderate level of intentions on halal food in low-cost airlines. The findings revealed that religion do have relationship with the intention toward halal food in low-cost airlines.
\end{abstract}

Keywords: Consumer intention, Halal food, Low-Cost airlines

\section{Introduction}

The low-cost airline or also being called the "no-frills" model in Europe because that airlines are only offer the basic services to their customers (Button, 2012). The low-cost approach in flight has a long history. The first successful low-cost carrier was Pacific Southwest Airlines in the United States, which initiated the concept in 1949, and companies like Southwest have been in business since the early 1970 (Gittell 2005). In the last five years, there are trend of budget Airlines in Malaysia and Southeast Asia with similar names such as Low-Cost Airlines and also Cheap Airlines (David, 2012). In Malaysia there several low-cost airlines for example AirAsia, Malindo Air and Firely. In-flight meal is one of the services offer in the low-cost airline. Free meals that usually offered by the full-services airlines are paid for in the higher priced ticket. In-flight meal in low-cost airline will charge the passenger (Godfrey, 2018).

Fuel price costs have caused the low-cost airlines to impose the fuel surcharges on customers as well (Mike, 2014). Non-government owned airlines have other issues as well beside of handling this fuel charges issue, yet this is their main issues of all. This fuel issue gets worse when there is economic recession. Therefore, the airlines believe that the ever-increasing fuel prices is impacting the ticket price that concern with the consumers. Overcapacity is another challenge facing by the consumers in low-cost airlines. This has 
led discomfort to the consumers which are also highlighted in a magazine as "Overcapacity in the market and declining yields continue to challenge the new Malaysia Airlines Bhd management" (Benjamin, 2018). According to Syed Shah Alam (2011), Muslim consumer is one of the largest markets caused by religious belief. But, compare to the other countries like Thailand and Indonesia, participation of Malaysia in halal market are consider low. Other countries can be said as faster halal centre in the region not Malaysia (Syed Syah Alam 2011).

In this study, the level of consumer Intention towards Halal Food in Low-Cost Airlines in Kelantan will be identified. The Theory of Planned Behaviour (TPB) will be use in order to determine the relationship between religion and consumers intention towards Halal food in low-cost airlines.

\section{Methodology}

This survey was done by using the quantitative method which the model Theory of Planned Behavior was applied. The conceptual framework is shown in Figure 1. The self-administered questionnaire was prepared and distributed to the 75 respondents purposively. The data were then recorded in SPSS software version 21.0. The data were analysed by using descriptive and Chi Square analysis.
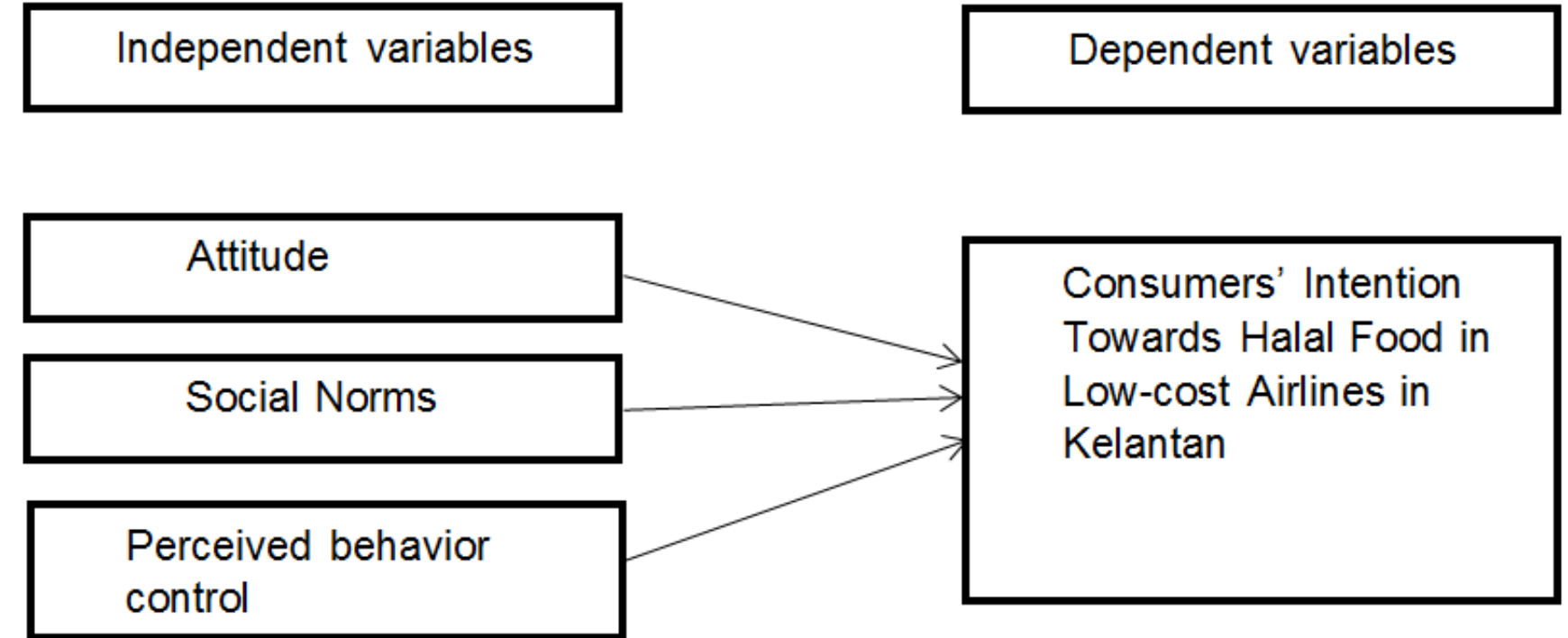

Figure 1. Adapted from TPB model (Sparks and Shepherd, 1992)

\section{Results and Discussion}

\subsection{Socio Demographic Profile}

The descriptive analysis was used to show and discuss the results of the demographic profile. Demographic profiles of the respondents are gender, age, religion, level of education, occupation, income, experienced in low-cost airlines, type of airlines used, and frequency in a year travel with low-cost airlines and experienced in in-flight meal. Table 1 shows the demographic profile of the respondents. The result is cover 75 respondents which is sampled from Sultan Ismail Petra Airport. Table 1 is summarized the background of respondents selected based on as gender, age, religion, level of education, occupation, income, experienced in low-cost airlines, type of airlines used, frequency in a year travel with low-cost airlines and experienced in inflight meal. Majority of respondents are female that is 41 (54.7\%) while only 34 respondents (45.3\%) are male. Most of the respondent's category age is about below 25 years old when 33 of respondent's age on that range (44.0\%), for age range of 26-35 have 21 respondents (28.0\%), age range of 56 years old and above were 9 respondents $(12.0 \%)$, age range of $36-45$ years were 8 respondents $(10.7 \%)$ while only 4 respondents $(5.3 \%)$ were at age range of 46-55 years old. After that, from 75 respondents, the religion is mostly from Islam which is $51(68.0 \%)$ respondents followed by Hindu which is 13 respondents (17.3\%), Christian which is 7 respondents (9.3\%) and lastly Buddha which is 4 respondents $(5.3 \%)$. The level education of the respondents based on 75 respondents are primary school/secondary school were 9 respondents (12.0\%), Diploma/STPM/Degree were 59 respondents (78.7\%) and it constitute the higher level of education among the respondents while from Postgraduate/ $\mathrm{PhD}$ only 7 respondents $(9.3 \%)$. Besides, the occupation of the respondents are mostly students with 26 respondents (34.7\%) followed by private sector with 23 respondents 
(30.7\%), self-employed with 12 respondents (16.0\%), government sector with 10 respondents (13.3\%) and lastly unemployed with 4 respondents (5.3\%). Among the respondents, 27 of them have income range of more than RM 3001 (36.0\%) while 20 of them have income range below RM 500 (26.7\%) which is mostly are students. For the income range of RM 1001- RM 2000 and RM 2001-RM 3000, both of it have 9 respondents $(12.0 \%)$ followed by 6 respondents (8.0\%) at income range of RM 501- RM 1000. But, there are 4 respondents $(5.3 \%)$ that are not interested in stating their income range. Majority respondents have already experienced low-cost airlines and 10 respondents (13.3\%) haven't experienced low-cost airlines. From respondents that experienced low-cost airlines, most of them are using Air Asia airline followed by Malindo Air with 9 respondents $(12.0 \%), 5$ respondents $(6.7 \%)$ using Firefly, 2 respondents $(2.7 \%)$ are using other airlines which is stated Jetstar Asia while only 1 of them using Lion Air (1.3\%). 46 respondents (61.3\%) have travelled by lowcost airlines in range of 1-5 times in a year. For the experienced of in-flight meal, 58 of respondents (77.3\%) have experienced it while 17 of them (22.7\%) did not experienced it.

Table 1.

Profile of interviewed respondents

\begin{tabular}{|c|c|c|c|}
\hline Characteristics & & Frequency (N) & Percentage (\%) \\
\hline \multirow[t]{2}{*}{ Gender } & Male & 34 & 45.3 \\
\hline & Female & 41 & 54.7 \\
\hline \multirow[t]{5}{*}{ Age } & $<25$ years & 33 & 44.0 \\
\hline & 26-35 years & 21 & 28.0 \\
\hline & $36-45$ years & 8 & 10.7 \\
\hline & $46-55$ years & 4 & 5.3 \\
\hline & $>56$ years & 9 & 12.0 \\
\hline \multirow[t]{4}{*}{ Religion } & Islam & 51 & 68.0 \\
\hline & Christian & 7 & 9.3 \\
\hline & Hindu & 13 & 17.3 \\
\hline & Buddha & 4 & 5.3 \\
\hline \multirow[t]{3}{*}{ Level of Education } & Primary School/Secondary School & 9 & 12.0 \\
\hline & Diploma/STPM/Degree & 59 & 78.7 \\
\hline & Postgraduate/PhD & 7 & 9.3 \\
\hline \multirow[t]{5}{*}{ Occupation } & Government & 10 & 13.3 \\
\hline & Private & 23 & 30.7 \\
\hline & Self-employed & 12 & 16.0 \\
\hline & Student & 26 & 34.7 \\
\hline & Unemployed & 4 & 5.3 \\
\hline \multirow[t]{6}{*}{ Income } & Less than RM 500 & 20 & 26.7 \\
\hline & RM 501-RM 1000 & 6 & 8.0 \\
\hline & RM 1001-RM 2000 & 9 & 12.0 \\
\hline & RM 2001-RM 3000 & 9 & 12.0 \\
\hline & More than RM 3001 & 27 & 36.0 \\
\hline & Not interested to stated & 4 & 5.3 \\
\hline \multirow{2}{*}{$\begin{array}{l}\text { Have you experienced low } \\
\text { cost airline? }\end{array}$} & Yes & 65 & 86.7 \\
\hline & No & 10 & 13.3 \\
\hline \multirow{5}{*}{$\begin{array}{l}\text { If yes, please choose which } \\
\text { airline }\end{array}$} & Air Asia & 49 & 65.3 \\
\hline & Malindo Air & 9 & 12.0 \\
\hline & Lion Air & 1 & 1.3 \\
\hline & Firefly & 5 & 6.7 \\
\hline & Others & 2 & 2.7 \\
\hline \multirow{4}{*}{$\begin{array}{l}\text { How many times in a year, } \\
\text { you travel by low-cost } \\
\text { airlines? }\end{array}$} & $\mathrm{O}$ & 7 & 9.3 \\
\hline & $1-5$ & 46 & 61.3 \\
\hline & $6-10$ & 8 & 10.7 \\
\hline & $>10$ & 14 & 18.7 \\
\hline \multirow{2}{*}{$\begin{array}{l}\text { Have you experienced in- } \\
\text { flight meal? }\end{array}$} & Yes & 58 & 77.3 \\
\hline & No & 17 & 22.7 \\
\hline
\end{tabular}




\subsection{The Intention's Level of Consumers toward Halal Food in Low-Cost Airlines}

According to the first objective of this study which is to identify the level of consumer's intention toward halal food in low-cost airlines. Table 2 summarized Mean score of the Attitude, Subjective Norms, Perceived Behavioural Control, and Consumer Intention toward Halal Food in Low-Cost Airlines in Sultan Ismail Petra Airport. Based on the findings of this study, intention was recorded as the highest mean score $(\mathrm{M}=2.59$, $\mathrm{SD}=0.62)$, followed by perceived behavioural control $(\mathrm{M}=2.49, \mathrm{SD}=0.60)$, attitude $(\mathrm{M}=2.43, \mathrm{SD}=0.70)$, and subjective norm $(\mathrm{M}=2.25, \mathrm{SD}=0.62)$. Since the intention level is high, we reject the null hypothesis of first hypothesis. As the result depict that consumers are mostly at an intention level toward halal food at low-cost airlines. The attitude and perceived behavioural control also indicate the high level toward Halal Food in Low-Cost Airlines. This result is equivalent to the study done by Ajzen (1991), which revealed that attitude is towards the target behaviour and subjective norms about attractive in such behaviour are considered to affect the intent in purchasing behaviour of halal food and includes perceived behavioural control that more engaging in the behaviour as a factor influencing intention and purchasing behaviour (Ajzen, 1991; Alam \& Sayuti, 2011).

Table 2.

Mean score of the Attitude, Subjective Norms, Perceived Behavioural Control, and Consumer Intention toward Halal Food in Kelantan.

\begin{tabular}{|l|l|l|l|l|l|}
\hline Factors & Frequency & Percentage & Mean & Standard Deviation & Level \\
\hline Attitude & & & 2.4267 & 0.70084 & High \\
\hline Low & 9 & 12.00 & & & \\
\hline Moderate & 25 & 33.30 & & & \\
\hline High & 41 & 54.70 & & & Moderate \\
\hline $\begin{array}{l}\text { Subjective } \\
\text { Norms }\end{array}$ & & & 2.2533 & 0.61717 & \\
\hline Low & 7 & 9.30 & & & \\
\hline Moderate & 42 & 56.00 & & & High \\
\hline High & 26 & 34.70 & & & \\
\hline $\begin{array}{l}\text { Perceived } \\
\text { Behavioural } \\
\text { Control }\end{array}$ & & & 2.4933 & 0.60120 & \\
\hline Low & 4 & & & & \\
\hline Moderate & 30 & 5.30 & & & High \\
\hline High & 41 & 40.0 & & & \\
\hline Intention & & 54.70 & & & \\
\hline Low & 5 & 6.70 & & & \\
\hline Moderate & 21 & 28.00 & & & \\
\hline High & 49 & 65.30 & & & \\
\hline
\end{tabular}

Notes: Mean values correspond to 1.00-2.33: low; 2.34-3.66: moderate; 3.67-5.00: high

Sources: Survey, 2018

\subsection{Relationship between Religion and Consumer Intention toward Halal Food in Low-Cost Airlines}

Inferential statistics is a study to make the judgement or conclusions of the probability that an observed varies between groups is one or more credible that might happen coincidentally in this study. This method is using to make inferences from the data to more general statements based one experimental or observations data collected (Trochim, 2006). There is different type of inferential statistics which includes Pearson Correlation, Multiple Regression Analysis, Chi-Square Statistic and confidence interval (Thing, Evon, Thye, \& Tien, 2014). Chi-square used to test whether the hypothesis should be rejected or not according to the value of p-value. Null hypothesis was failed to reject when there was no significant difference between demographic factor and independent variable. When result showed there was a significant difference between variables, then it can conclude that variables were found to be related. The degrees of freedom, often written as df or d, describes how many numbers are independent in the grid (Ling, 2008). In table 3, we can see that the Asympototic Significance is 2-sided, which it means the value should be less than 0.05 (Anon, 2014). The chisquare result of the study is 122.295 with $69 \mathrm{df}, \mathrm{p}=0.000$. From the finding, it is showed that the religion has significant difference with the intention toward halal food in low-cost airlines. Religiosity directly and 
significantly influenced intention towards purchasing Halal foods (Haslinda \& Marso, 2017; Elif \& Nurdan, $2017)$.

Table 3.

Results of Chi-square Analysis between Religion and Consumer Intention toward Halal Food in Low-Cost Airlines.

\begin{tabular}{|l|l|l|l|l|}
\hline & & Value & df & Asymp. Sig. (2-sided) \\
\hline \multirow{2}{*}{ Religion } & Pearson Chi-Square & $122.295^{\text {a }}$ & 69 & 0.000 \\
\cline { 2 - 5 } & N of valid case & 75 & & \\
\hline
\end{tabular}

Sources: Survey, 2018

\section{Conclusion}

The result of this study showed that consumer intention towards Halal food in low- cost airline is in moderate level. Based on the mean score result from this study, the moderate level shows the moderation of the intention of consumers towards Halal food in low-cost airline which depends on the attitude, subjective norm and perceive behaviour of the consumer. Besides that, religion does have relationship between the consumer intentions towards Halal food in low-cost airline. Malay consumer in general plays an important role towards the intention of Halal food. This may happen because the respondents of this study are mostly Malays and Muslims. In fact, as we all know, the official religion in Malaysia is Islam. Therefore, it is certain that the intention of Halal food in low - cost airline is very important for most users.

\section{References}

Ajzen, I. (1991). The theory of planned behavior. Organizational Behavior and Human

Decision Processes, $50(2), 179-211$

Alam, S.S. \& Mohamed Sayuti, N. (2011). "Applying the Theory of Planned Behavior (TPB) in Halal food purchasing". International Journal of Commerce and Management, 21(1), pp. 8-20.

Anon. 2014. Practical Applications of Statistics in the Social Sciences - University of Southampton. Retrieved April 28, 2018 from https://cdn.southampton.ac.uk/assets/imported/transforms/contentblock/UsefulDownloads_Download/CO4DB441CDB34B209B1A14142FDAC245/PASSS\%20RQ4\%20Chi\%20Sq $\underline{\text { uare.pdf }}$

Benjamin, E. 2018. Malaysia Airlines continues to face challenges in over-saturated market. Retrieved April 27, 2018, from http://www.theedgemarkets.com/article/malaysia- $\quad$ airlines-continues-face-challengesoversaturated-market

Button, K. J. 2012. Low - cost Airline: A Failed Business Model? George Mason University. Transportation Journal. 51. 10.5325/transportationj.51.2.0197.

David, Jr. (2012). Budget Airlines. Retrieved April 27, 2018, from https://blog.malaysiaasia.my/2011/08/budget-airlines.html.

Elif E. H. and Nurdan, S. 2017. Evaluation of Halal Food Purchase Intention in Germany. International Journal of Contemporary Applied Researches, 4(9), 7-15.

Gittell, J. F. 2005. The Southwest Airlines Way. New York: McGraw-Hill. Business Processes and Market Environment, Berlin 2007.

Godfrey, K. (2018). Passenger charged up to 8900 percent more for food and drink on 24, 2018 from https://www.express.co.uk/travel/articles/937708/plane-food-cost-airline-meal- p passengers.

Haslinda, H. and Marso, M. 2017. Religiosity and Its Consequences In Halal Food Purchasing Behavior (An Empirical Evidence From Tarakan, Indonesia And Tawau, Malaysia). International Journal of Research Science \& Management. $\quad 1-7$.

Ling. 2008. Pearson's Chi-square Test for Independence. Retrieved April 27, 2018, from https://www.ling.upenn.edu/ clight/chisquared.htm

Mike, E. 2014. As oil prices fall, the fuel surcharge debate escalates. Retrieved May 20, https://www.advito.com/as-oil-prices-fall-the-fuel-surcharge-debate- escalates/

Syed, S. A., Rohani, M., and Badrul, H. (2011) "Is religiosity an important determinant on behaviour in Malaysia?", Journal of Islamic Marketing, Vol. 2 Issue: 96, https://doi.org/10.1108/17590831111115268

2018

from

Muslim consumer 1, pp.83-

Thing, E. L., Evon, K., Thye, S. H., and Tien, T. E(2014) A Study of Consumers' Purchase Intention Toward Green Food. Final Year Project, UTAR.

Trochim, W.M. (2006). Inferential Statistics. Retrieved May 20, 2018, from https://socialresearchmethods.net/kb/statinf.php 